\title{
Assessing the Efficiencies and Competitiveness of the Fresh Cassava Storage Root Production Systems in Sierra Leone
}

\author{
Osman Nabay ${ }^{1}$, James B. A. Whyte ${ }^{1,2}$, Brice J. Gbaguidi ${ }^{2}$, Vodouhé G. Tonakpon ${ }^{2}$, Fallah S. Kassoh ${ }^{1}$, \\ Tamba Bandabla ${ }^{1}$, Martin Koroma ${ }^{1}$, Keiwoma M. Yila ${ }^{1}$, Lansana Sesay ${ }^{1}$, \\ Alhaji Massaquoi ${ }^{1} \&$ Raymond Bangura ${ }^{1}$ \\ ${ }^{1}$ Sierra Leone Agricultural Research Institute (SLARI), Sierra Leone \\ ${ }^{2}$ International Institute of Tropical Agriculture (IITA), Sierra Leone and Benin \\ Correspondence: Osman Nabay, Sierra Leone Agricultural Research Institute (SLARI), Njala Agricultural \\ Research Centre (NARC), Freetown, P.O. Box 540, Sierra Leone. Tel: 232-(76)-818-134. E-mail: \\ nabayosman@yahoo.com
}

Received: July 16, 2017

Accepted: September 28, $2017 \quad$ Online Published: November 15, 2017

doi:10.5539/jas.v9n12p178

URL: https://doi.org/10.5539/jas.v9n12p178

The research is financed by the Government of Sierra Leone through the West African Agricultural Productivity Program (WAAPP-SL).

\begin{abstract}
The Policy Analysis Matrix (PAM) was used to assess the efficiencies and competitiveness of fresh cassava storage root production systems in Sierra Leone. Proportional random sampling was used to select study samples. Information was collected using structured questionnaire from a total of 1,880 producer households. Out of the 36 potential storage root production systems identified, only 6 systems are mainly used by producers. The PAM was based on one hectare of land for production and Leone (SSL) as money to evaluate costs and revenues. The analysis indicates that, all the 6 fresh cassava storage root production systems present a Domestic Resource Cost Ratio of less than 1 (DRC < 1) and Cost-Benefit Ratio (RCB) also less than 1 (RCB within 0.14 to 0.42 ). Discounting potential revenue from stems and cassava leaves in storage root production systems that use improved varieties and fertilizer have higher comparative and competitive advantages. The systems are also profitable, even though producers are not protected from tradable and taxed inputs. Production systems also remain profitable with $25 \%$ and $50 \%$ yield loss. This was also confirmed by Abiodun and Adefemi (2016). It is therefore better to produce cassava locally in Sierra Leone than import for processing or consumption. This study proposes recommendations to improve cassava productivity in Sierra Leone.
\end{abstract}

Keywords: competitiveness, cost-benefit ratio, domestic resource cost ratio, efficiencies, fresh cassava storage root production systems

\section{Introduction}

In Sub-Saharan Africa, cassava (Manihot esculenta Crantz) is the second most important food staple after maize and it's very important not just as a food security crop but as a major source of income for a large population particularly farmers who cultivate the crop on farms that are often regarded as fallow. The crop also grows very well on marginal soils and also replaces crops that require greater soil fertility (NISER, 2013; Hillocks, 2002). According to Westby (2008), the total world cassava demand would reach 275 million tons by 2020. Presently, Africa produces about 62 per cent of the total world cassava production with Nigeria being the largest producer of the crop in the world with output level of 54 million tons in 2013 (FAOSTAT, 2015).

Despite this favourable production statistics, sub Saharan Africa lags behind global trends in development of the cassava value chains. It has been estimated that, $95 \%$ of the production is still through resource limited subsistence farming oriented to household consumption with surpluses traded in fresh roots and traditional processed forms (Nweke et al., 2002). The tender leaves and shoots are also eaten as vegetables providing proteins, vitamins and minerals (Dahniya, 1994).

Aside its food security and famine reserve role, cassava also possesses high economic potential when exploited as raw material/feedstock for different food, feed and non-food industrial applications through import 
substitution and exports markets opportunities. Nonetheless, less than five per cent of the output produced in Nigeria is used in the industries while about 95 per cent is used for human consumption (NISER, 2013). Industrial users of cassava products in many countries consisted mainly of bakeries, flour mills, livestock and pharmaceutical firms.

Nweke et al. (2002) and Nweke (2004) identify four key factors that have driven cassava commercialization in West Africa viz., a) high rural and urban households demand which drove producer incentive to expand production, b) IITA's high-yielding Tropical Manioc Selection (TMS) varieties that boosted cassava yields by at least $40 \%$ without fertilizer application, c) the Africa-wide biological control program that averted the devastating cassava mealy bug epidemic and d) the use of the mechanical grater to release labour from gari processing for planting. These technologies have successfully driven down the price of cassava to consumers by reducing the cost of cassava production, harvesting, and processing. Labour saving technologies are now needed to address constraints associated with harvesting and peeling cassava roots.

In Sierra Leone, Cassava production is all over and the Northern Province is the highest cassava producing region followed by the South. Cassava is mostly grown in mixture with other crops particularly upland rice by majority farmers. However, mix-cropping of cassava and rice is more predominant and widespread in the South and East of Sierra Leone than in the North (Mahmood, 2016; MAFFS/PEMSD, 2015). Cassava is mostly produced by smallholder farmers with an average land holding averaging from 0.5-2.0 hectares and contributed $6 \%$ of the agricultural GDP in 2010 (SSL, 2010). Cassava can be consumed fresh, or in a variety of processed forms (gari, fufu, starch, chips, flour/bread, and others). Other uses (animal feed, organic fertilizers and ethanol biofuel) are limited in Sierra Leone (MAFFS 2009a).

However, cassava production has been increasing since the end of the conflict through the effort of Sierra Leone Agricultural Research Institute (SLARI) and International Institute of Tropical agriculture (IITA). The latest production results show that, production has increased from 3,250,044 tons in 2010 to 4,135,064 tons in 2014. It is clear that, increase in production is entirely as a result of increase yield from 8 to $15 \mathrm{hg} / \mathrm{ha}$ from 2010 to 2014 and the area under cultivation decreases from 394,902 ha in 2010 to 393,839 ha in 2014, (FAOSTAT, 2015).

Cassava yields are relatively low, with some estimates as low as $5 \mathrm{MT} /$ ha, though the average in Sierra Leone is 8-15 MT/ha for 2010 to 2014 and can go to as high as 20-40 t/ha of available improved cassava varieties (SLICASS) depending on varieties and inputs used. The low yield on farmer's field could largely be attributed to poor management practices (agronomic techniques), less use of inputs (Agro-chemical and Machineries), and the predominant use of traditional varieties which are susceptible to the yield reducing cassava mosaic disease (Mahmood, 2016).

Although improved varieties yield higher than local cultivars and are suitable for processing they may not necessarily fit into the recommended range for commercial production or have characteristics required for target high value products. Supply to industrial users need programmed cultivation, harvesting and use of homogeneous varieties but industrial level processing pre-empts large-scale production systems which can limit reliance on small-scale farmers unless linked through contracting, vertical integration and inclusive business models.

Market opportunities are currently significant for cassava with growing demand in domestic, regional and international market but Smallholder have not been able to respond effectively to exploit these opportunities because of a number of structural and institutional constraints that limit market participation. Transforming the status of the cassava sector in Sierra Leone from subsistence to commercial level will require comprehensive sector information to specify and analyse opportunities, constraints/needs and propose areas for technological, institutional, organizational and policy interventions for production, utilization and marketing

The study therefore aims to assess the efficiencies and competitiveness of the fresh cassava storage root production systems in Sierra Leone. Specifically the study was designed to determine socio-economic characteristics of cassava producers; to assess the efficiencies and competitiveness of the cassava production systems; to determine the profitability and margins for those production systems; to identify their major opportunities and constrains and suggest possible recommendations in order to improve its competitiveness in support of stakeholder livelihoods and economic development of the country.

\section{Methodology}

\subsection{Description of Study Location}

Sierra Leone is in the lowland humid tropics located on the West Coast of Africa between latitude $6^{\circ} 55^{\prime} \mathrm{N}$ and $10^{\circ} 00^{\prime} \mathrm{N}$ and longitude $10^{\circ} 16^{\prime} \mathrm{W}$ and $13^{\circ} 18^{\prime} \mathrm{W}$ and covers an area of $71,740 \mathrm{~km}^{2}$ (Sierra Leone CFSVA, 2011). It 
borders Guinea in the north and northeast and Liberia in the east and southeast. The country has a population of $5,743,000$ people (National Population Census 2004), about 70\% of this leaves is in rural areas, and engage in small holder agricultural production and contributes at least 45 percent to the country's gross domestic product (GDP).

The country has a tropical climate with four main types of vegetation: forest, savannah, grassland and swamp, it's also divided into four provinces: northern, southern eastern and the western area with two main seasons: the rainy season lasts about seven months from April to November peaking in July and August and the dry season lasts from December to May. Each province is divided into districts and each district is subdivided into chiefdoms.

This study was a nationwide study on cassava production in Sierra Leone.

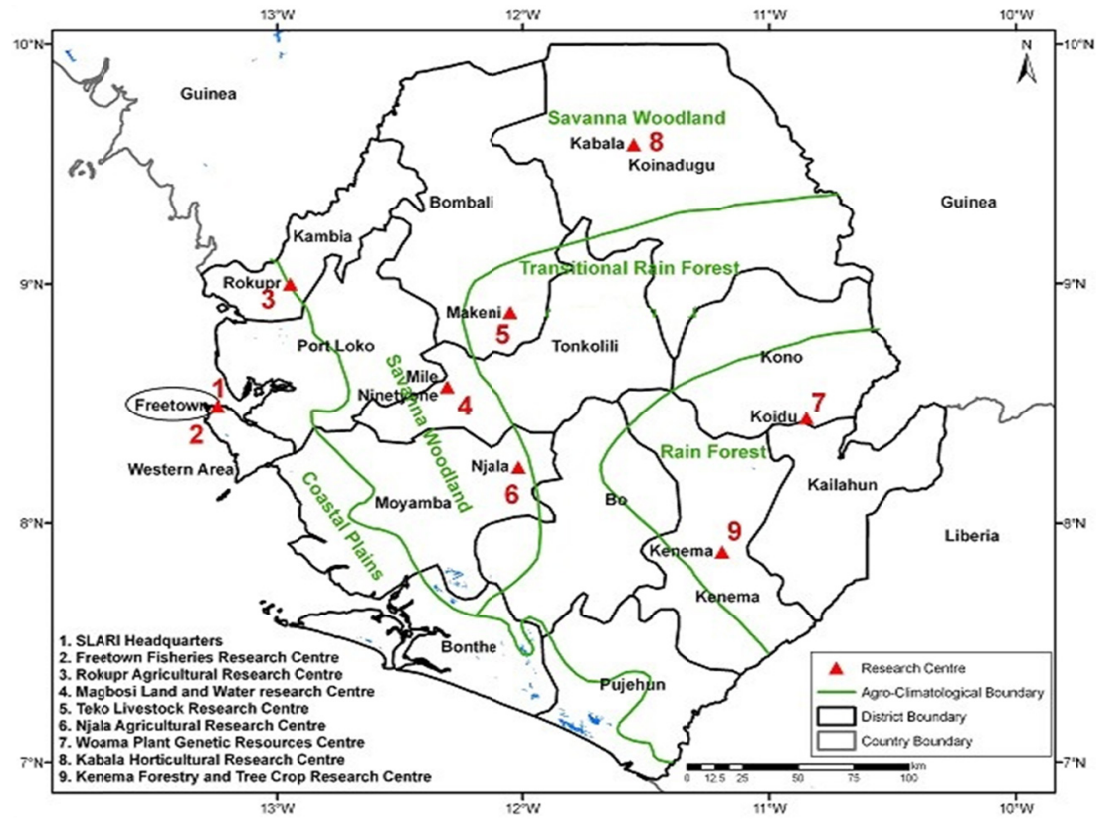

Figure 1. Major ecological zones in Sierra Leone

\subsection{Sampling Frame and Methods/Survey Design}

Sierra Leone is divided into four regions: Eastern, Northern, Southern and Western Regions. Each of the regions is divided into districts of unequal sizes. Each district is divided into chiefdoms, which are in turn are divided into enumeration areas (EAs). EAs contain 100 households on average and may contain several villages within their boundaries. EAs are the basic administrative unit that is used by Statistics Sierra Leone (SSL) for the purpose of conducting censuses or surveys. The 2004 Housing and Population Census divided Sierra Leone into 9,673 EAs. This was used as the sampling frame for this survey.

Proportional random sampling was used to select the study sample. There are 14 districts in Sierra Leone and each was consider as strata. Each of those was stratified into two, this is urban and rural.

\subsection{Sampling Size and Selection}

From a list obtained from Sierra Leone statistics, the target population of the study area was known. That target population was then used to determine the sample population using Cochran's (1977) sample selection formula.

$$
n=\frac{N}{1+N(e)^{2}}
$$

Where, $n$ is the sample size of farming households, $N$ is the total number of farming households to be sampled and $e$ is the level of precision (which, in this case is the $95 \%$ confidence level). 
In the sample frame, all the districts were considered unless Western Urban since there is no cassava production/farming in large scale. A sample size of 94 enumeration areas (EAs) was calculated and allocated using proportional random sampling method to all the districts.

The sample selection was done in three stages. The first stage was the selection of the chiefdoms in a district, the second stage was the selection of the EAs from the selected chiefdoms, and third stage was the selection of twenty households from each of the selected EAs. The number of chiefdom selected from a district depended on the total number of EAs allocated to that district. Also the total number of EAs selected from each district and the selected chiefdoms was divided into rural and urban EAs according to the proportion in which they are in the district and chiefdom.

To select the twenty households from the selected EAs, enumerators first listed the total households in each of the selected EAs and then a random selection of the twenty households was done using the random number table. The household modules were then administered to the selected households. These brought the sample sizes of the household to 1880 for the producers.

\subsection{Data Collection}

Information for the studies was collected using well-structured questionnaire, personal interviews and enumerators' field observation. Data collected includes cost and return variables and other socioeconomic data. The producers modules were household questionnaires and the household modules were then administered to the selected households.

\subsection{Database Design}

Data entry template was designed in the Census and Survey Processing Software (CSPro) for the producers' questionnaires. Personnel were trained to do the data entry. The captured data were then exported into STATA and the Statistical Package for Social Scientist (SPSS) databases.

\subsection{Data Analysis and Presentation}

The exported data was analysed using the Statistical Analysis System (SAS 9.4), Statistical Package for Social Sciences (SPSS) and Microsoft Office Excel 2007. A combination of qualitative (thematic and SWOT analysis) and quantitative methods of analysis was used to analysed the data.

Socio-economic characteristics of respondents were summarized by the use of frequency distribution tables and proportion/percentages. A "Policy Analysis Matrix" (PAM) framework was used to assess the efficiencies and competitiveness and also the profitability and margins in each selected fresh cassava storage roots production system. Policy Analysis Matrix (PAM), mainly Domestic Resource Cost Ratio (DRC) and Cost-Benefit Ratio (CBR) were used. PAM also considers the effect of the agricultural production environment on farmer productivity exploring the potential effects of various proposed policy interventions. The SWOT was used to identify the major opportunities and constraints along the cassava production systems.

2.6.1 Methodology Used in Assessing the Efficiencies and Competitiveness of Fresh Cassava Storage Root Production Systems

Before performing Policy Analysis Matrix (PAM), all the production systems are identified and the common ones are selected for PAM.

The Policy Analysis Matrix (PAM) measures the economic efficiency and comparative advantage of producing commodities or using agricultural and Natural Resources Management (NRM) technologies. PAM analyses the private (financial) and social (economic or reference) profitability of alternative resource and crop management technologies.

\section{(1) Steps Followed to Perform Policy Analysis Matrix (PAM)}

$>$ Identification of the production systems of fresh cassava storage roots: For fresh cassava storage root production systems 36 systems were identified and the common ones were selected for PAM analyses. The 36 systems can be found at the Table 10 below:

$>$ Determination of number of producers in each selected production system;

$>$ Determination of physical quantities of imported (tradable) and local factors(domestic factors) of production including small equipment and materials for the manufacture of a given quantity of the product and the volume of the final product released;

$>$ Calculation of financial and economic price (unitary) for each input Economic price $=$ Market price-taxes + subvention. The market prices are the prices of different products (inputs and outputs) in the local market; 
Calculation of financial and economic costs for all quantities inputs;

$>$ Calculation of financial and economic revenues for the volume of the final output released;

> Calculation of financial and economic profits for the volume of the final output released;

$>$ Building the Policy Analysis Matrix (Table 1).

Table 1. Policy analysis matrix

\begin{tabular}{llllll}
\hline \multirow{2}{*}{ Budgets } & \multirow{2}{*}{ Revenue } & \multicolumn{2}{c}{ Costs } & & Net \\
\cline { 3 - 4 } & & Tradable goods & Domestic factors & & Profit \\
\hline Budget at market price & $\mathrm{A}=\mathrm{P}_{\mathrm{f}} \cdot \mathrm{Q}$ & $\mathrm{B}=\mathrm{P}_{\mathrm{t}} \cdot \mathrm{Q}_{\mathrm{t}}$ & $\mathrm{C}=\mathrm{P}_{\mathrm{n}} \cdot \mathrm{Q}_{\mathrm{n}}$ & & $\mathrm{D}(1)=\mathrm{A}-\mathrm{B}-\mathrm{C}$ \\
Budget at social price & $\mathrm{E}=\mathrm{P}_{\mathrm{e}} \cdot \mathrm{Q}$ & $\mathrm{F}=\mathrm{P}_{\mathrm{i}} \cdot \mathrm{Q}_{\mathrm{i}}$ & $\mathrm{G}=\mathrm{P}_{\mathrm{d}} \cdot \mathrm{Q}_{\mathrm{d}}$ & & $\mathrm{H}(2)=\mathrm{E}-\mathrm{F}-\mathrm{G}$ \\
Divergences & $\mathrm{I}(3)=\mathrm{A}-\mathrm{E}$ & $\mathrm{J}(4)=\mathrm{B}-\mathrm{F}$ & $\mathrm{K}(5)=\mathrm{C}-\mathrm{G}$ & & $\mathrm{L}(6)=\mathrm{I}-\mathrm{J}-\mathrm{K}$ \\
\hline
\end{tabular}

Note. A, B, and C: Represents products at market price; $(\mathrm{P}, \mathrm{Q})$ : The vector of quantities representing production activities; $\left(\mathrm{P}_{\mathrm{t}} \cdot \mathrm{Q}_{\mathrm{t}}\right)$ : Tradable inputs (Import-Export); $\left(\mathrm{P}_{\mathrm{n}} \cdot \mathrm{Q}_{\mathrm{n}}\right)$ : Non-tradable (domestic factors). These are elements which go into the financial analysis of the budget; E, F, and G: Represent those elements which are considered during the economic analysis of the budget; I, J, K, and L: Represent the difference between the financial budget and the economic budget (A-E, B-F, C-G, D-H); it measures policy-induced transfers that come into play due to policy-induced market failures or distortions.

(2) Calculation and Interpretation of the Key Indicators and Ratios

(i) Domestic Resource Cost Ratio (DRC): $\mathrm{DRC}=\mathrm{G} /(\mathrm{E}-\mathrm{F})$

This is the relative cost in terms of domestic resources of producing a unit quantity of output instead of importing it. DRC is the main indicator for assessing the efficiencies and competitiveness of cassava value chains. The production of the commodity represents an efficient use of domestic resources.

Any DRC less than 1 indicates an international comparative advantage in production of the commodity. The country is better off producing than importing the specified commodity.

DRC $<1$ : Comparative Advantage. As such, it is better for the country to produce the commodity locally than import it.

Any DRC greater than 1 means that the economy is incurring costs in excess of what it gains or saves from the production of the specified commodity in terms of foreign exchange.

DRC $>1$ : The country stands a high risk of producing the commodity at high cost with respect to what it will receive as foreign earnings.

Finally a DRC $=1$ indicates that the economy neither gains nor saves foreign exchange through domestic production. It is a summary measure of the relative efficiency of domestic production and can be used by researchers and research managers to decide on resource allocation between technologies.

$\mathrm{DRC}=1$ : The balance of the economy does not gain or lose in terms of foreign earnings.

(ii) Cost-Benefit Ratio (CBR): $\mathrm{CBR}=(\mathrm{F}+\mathrm{G}) / \mathrm{E}$

The Cost-Benefit Ratio is the ratio of costs (tradable and domestic costs) over the gross benefits. Cost and benefits are evaluated using the economic price (shadow price or opportunity cost).

The Cost-Benefit Ratio is the ratio of costs (tradable and domestic costs) over the gross benefits.

$\mathrm{CBR}<1$ : The production activity is economically profitable;

$\mathrm{CBR}>1$ : The production activity is not economically profitable;

$\mathrm{CBR}=1$ : The production activity does not cause any loss or profit.

(iii) Nominal Protection Coefficient (NPC) on Tradable Outputs and on Tradable Inputs

$\mathrm{NPC}$ on tradable outputs $(\mathrm{NPCO})=\mathrm{A} / \mathrm{E}$;

$\mathrm{NPC}$ on tradable inputs $(\mathrm{NPCI})=\mathrm{B} / \mathrm{F}$.

The NPC compares domestic and international prices, adjusted for marketing costs and exchange rates. 
Any differences in these prices will result in an NPC not equal to 1, and can be attributed to the policy regime and market efficiency.

$\mathrm{NPC}=1$ : would show full Pareto-optimal competitive trade between domestic and foreign markets;

NPC $<1$ : indicates an implicit tax on production (subsidy in case of inputs);

NPC $>1$ : indicates implicit subsidy on production (tax in case of inputs).

(iv) Effective Protection Coefficient (EPC): $(\mathrm{A}-\mathrm{B}) /(\mathrm{E}-\mathrm{F})=\left(\mathrm{P}_{\mathrm{f}} \cdot \mathrm{Q}_{\mathrm{f}}-\mathrm{P}_{\mathrm{t}} \cdot \mathrm{Q}_{\mathrm{t}}\right) /\left(\mathrm{P}_{\mathrm{e}} \cdot \mathrm{Q}_{\mathrm{e}}-\mathrm{P}_{\mathrm{i}} \cdot \mathrm{Q}_{\mathrm{i}}\right)$

The EPC combines the two NPCs to assess the effect of implicit tax and subsidy through both output and inputs. The result is a ratio of value added at private prices to value added at social prices, indicating the effect of protection on value added and captures the incentive impact of policy on the production structure.

The difference between the NPC and the EPC is that the EPC takes output prices and the cost of traded inputs into account simultaneously.

CPE $>1$ : the actors of the considered "value chains" earn more income than they would gain without distorting prices. Producers receive an implicit subsidy on input and/or have a protection of the product price.

$\mathrm{CPE}=1$ : reflects the balance or the optimal level of trade competitiveness between the national and international market. The protective structure is neutral. Producers are neither favoured nor disadvantaged.

$\mathrm{CPE}<1$ : means that the country does not protect its market. Product is implicitly taxed. Producers gain a better income in the international market. They are disadvantaged in the internal market. They buy and sell at economical prices.

(v) Subsidy Ratio to Producers (SRP): L/E or (D - H)/E

\subsubsection{Methodology Used in Determining Profitability and Marketing Margin}

Profitability or gross margin can be defined as the difference between revenue and costs. The profitability measures the performance of the activity. There are 2 types of profitability: Private Profitability and Social Profitability.

(1) Private Profitability (D)

As indicated above, the term private refers to observed revenues and costs reflecting actual market prices received or paid by farmers, traders or processors in the production systems. The Private profit (D) or market margin is the difference between revenues $(A)$ and costs $(B+C)$ and in this case indicates the competitiveness based on private price (actual or market price) of output; hence, profit (D) is excess profit-above-normal return to operators of the activity. If private profit is negative $(\mathrm{D}<0)$, operators are earning a subnormal rate of return and are expected to come out of this business, unless something changes to increase profit to at least a normal level $(\mathrm{D}=0)$. Alternatively, positive private profit $(\mathrm{D}>0)$ is an indication of returns above the normal and should lead to a future expansion of the system, unless the system provides no more possibility of extension or existing alternative activities provide better profits.

(2) Social Profitability $(\mathrm{H})$

The Social profitability $(\mathrm{H})$ or economic margin is an indicator which measures comparative advantage or efficiency in the commodity value chains under the condition of no divergence from the government policies and market distortions. Efficient outcomes are achieved when an economy's resources are used in activities that create the highest levels of output and income. Social profits, H, are an efficiency measure because outputs, E, and inputs, $\mathrm{F}+\mathrm{G}$ (table below), are valued in prices that reflect scarcity values or social opportunity costs. Social profits, like the private analogue, are the difference between revenues and costs, all measured in social prices- $\mathrm{H}=(\mathrm{E}-\mathrm{F}-\mathrm{G})$. If $\mathrm{H}$ positive, this means the system of production of the commodity gain profit at the expense of normal social cost and can be given priority in development. But when, social profits are negative, the system cannot survive without assistance from the government. Such systems waste scarce resources by producing at social costs that exceed the costs of importing. The choice is clear for efficiency-minded economic planners: enact new policies or remove existing ones to provide private incentives for systems that generate social profits, subject to non-efficiency objectives.

\section{(3) Profitability Coefficient (PC)}

The ratio of private and social profits or $\mathrm{PC}=(\mathrm{A}-\mathrm{B}-\mathrm{C}) /(\mathrm{E}-\mathrm{F}-\mathrm{G})$, or $\mathrm{D} / \mathrm{H}$ measures the incentive effects of all policies and thus serves as an estimation of the net policy transfer, since $L=(D-H)$. It shows the extent to which private profits exceed social profits. But, its usefulness is restricted when private or social profits are negative, 
since the signs of both entries must be known to allow clear interpretation. If the $\mathrm{PC}>0$, it means that the overall government policy provides incentives to producers for the commodity.

\section{Results and Discussions}

\subsection{Socioeconomic Characteristics of Producers}

Table 3 below revealed that, $(86.11 \%)$ of the respondents within the study areas were male and $(13.81 \%)$ are female. Within the study area, Northern region was dominated with $(38.07 \%)$, Eastern region with $(25.84 \%)$ and Southern region with (21.08\%) and the least percentage of the respondents interviewed fall in Western area. This implies that the highest percentage of the Northern region is as a result of the largest in terms of population size (SSL 2010).

From Table 3, the majority of the respondents $(42.52 \%)$ fell within 40 and 50 years of age. Within the study area, Northern region dominate with percentage of $(19.12 \%)$, second by Southern region with percentage of $(11.27 \%)$, Eastern region with $(11.6 \%)$ and Western area with the least percentage $(0.53 \%)$. This implies that the respondents are very active to engage in productive economic activities that will generate income for the household (Basu et al., 1998).

Out of the respondents interviewed, (92.41\%) were married. Within that percentage, the Northern region is the highest $(40.15 \%)$, seconded by Eastern region with (28.76\%) and Southern region with $(22.1 \%)$ and Western area with the least $(1.4 \%)$. The probable reason for the difference is the fact that majority of the rural people were challenge with the responsibility of early marriage and they regard it as this would help them to farm in large area due to increase in household size labour (Elijah et al., 2006).

Table 3 shows that, $(54.3 \%)$ of the respondent have never attained any formal education. From that percentage, Northern region has $(27.6 \%)$, Eastern region with $(14.29 \%)$, Southern region with $(11.79 \%)$ and Western area with the percentage $(0.62 \%)$. This finding is in consonance with Oyekanmi and Okeleye (2007) results. Which show that, $82.8 \%$ of the farmers are illiterate while only $17.2 \%$ of the farmers were found to be literate.

\subsection{Efficiencies and Competitiveness of the Fresh Cassava Storage Root Production Systems}

In the calculation of indicators of the PAM, the following considerations were made:

$>\quad$ The basis for fresh cassava storage root, the Leone (SSL) currency was used to evaluate costs and revenues per hectare of cassava production.

$>$ On fresh cassava storage root production, the following inputs and outputs listed in Table 2 were considered.

Table 2.Different inputs and outputs from root value chain

\begin{tabular}{lll}
\hline Production factors & & Products \\
\hline Activities & Inputs & Outputs \\
\hline Brushing & Land rent & Cassava root \\
Burning & Cuttings & Cassava stems \\
Clearing & Hoe & Cassava leaves \\
Ploughing & Axe & \\
Ridging & Cutlass & \\
Cutting preparation & Fertilizer & \\
Planting & Basket & \\
Weeding & & \\
Fertilizer application & & \\
Harvesting & & \\
\hline
\end{tabular}

Source: Field survey data, 2013. 
Table 3. Socio-economic characteristics of the producers

\begin{tabular}{|c|c|c|c|c|c|c|c|c|c|c|}
\hline \multirow{3}{*}{ Variables } & \multicolumn{8}{|c|}{ Regions } & \multirow{2}{*}{\multicolumn{2}{|c|}{ Total }} \\
\hline & \multicolumn{2}{|c|}{ Eastern } & \multicolumn{2}{|c|}{ Northern } & \multicolumn{2}{|c|}{ Southern } & \multicolumn{2}{|c|}{ Western Area } & & \\
\hline & Frequency & Percentage & Frequency & Percentage & Frequency & Percentage & Frequency & Percentage & Frequency & Percentage \\
\hline \multicolumn{11}{|l|}{ Gender } \\
\hline Male & 391 & 25.84 & 576 & 38.07 & 319 & 21.08 & 17 & 1.12 & 1303 & 86.11 \\
\hline Female & 72 & 4.76 & 83 & 5.49 & 45 & 2.9 & 10 & 0.66 & 210 & 13.81 \\
\hline \multicolumn{11}{|l|}{ Age (yrs.) } \\
\hline $20-39 \mathrm{yr}$ & 197 & 12.99 & 251 & 16.55 & 137 & 9.03 & 13 & 0.86 & 598 & 39.43 \\
\hline $40-59 \mathrm{yr}$ & 176 & 11.6 & 290 & 19.12 & 171 & 11.27 & 8 & 0.53 & 645 & 42.52 \\
\hline $60-79 \mathrm{yr}$ & 77 & 5.08 & 87 & 5.74 & 46 & 3.03 & 4 & 0.26 & 214 & 14.11 \\
\hline$<=19$ yrs & 9 & 0.59 & 23 & 1.52 & 7 & 0.46 & 1 & 0.07 & 40 & 2.64 \\
\hline$>79$ yrs & 5 & 0.33 & 10 & 0.66 & 4 & 0.26 & 1 & 0.07 & 20 & 1.32 \\
\hline \multicolumn{11}{|l|}{ Marital status } \\
\hline Married & 432 & 28.76 & 603 & 40.15 & 332 & 22.1 & 21 & 1.4 & 1388 & 92.41 \\
\hline Single & 6 & 0.4 & 30 & 2 & 17 & 1.13 & 3 & 0.2 & 56 & 3.73 \\
\hline widow/widower & 14 & 0.93 & 17 & 1.13 & 11 & 0.73 & 2 & 0.13 & 44 & 2.92 \\
\hline Divorce/Separated & 7 & 0.47 & 3 & 0.2 & 3 & 0.2 & 1 & 0.07 & 14 & 0.94 \\
\hline \multicolumn{11}{|l|}{ Educational status } \\
\hline None & 206 & 14.29 & 398 & 27.6 & 170 & 11.79 & 9 & 0.62 & 783 & 54.3 \\
\hline Literate/Koranic & 57 & 3.95 & 83 & 5.76 & 86 & 5.96 & 3 & 0.21 & 229 & 15.88 \\
\hline Primary & 95 & 6.59 & 39 & 2.7 & 48 & 3.33 & 1 & 0.07 & 183 & 12.69 \\
\hline Junior high school & 45 & 3.12 & 20 & 1.39 & 18 & 1.25 & 6 & 0.42 & 89 & 6.18 \\
\hline Senior high school & 45 & 3.12 & 22 & 1.53 & 18 & 1.25 & 1 & 0.07 & 86 & 5.97 \\
\hline Tertiary none graduate & 4 & 0.28 & 23 & 1.6 & 7 & 0.49 & 2 & 0.14 & 36 & 2.51 \\
\hline $\begin{array}{l}\text { Tertiary graduate/ } \\
\text { post graduate }\end{array}$ & 7 & 0.49 & 1 & 0.07 & 3 & 0.21 & 0 & 0 & 11 & 0.77 \\
\hline Other & 2 & 0.14 & 9 & 0.62 & 14 & 0.97 & 0 & 0 & 25 & 1.73 \\
\hline
\end{tabular}

Source: Field Survey Data, 2013

Based on the survey, 36 potentials cassava root production systems have been identified (See Table 10 below) in Sierra Leone. Only 6 systems are commonly used by the farmers (Table 4) and of course selected for PAM analysis.

Table 4. Fresh cassava storage root production systems

\begin{tabular}{|c|c|c|c|}
\hline Production Systems & $\begin{array}{l}\text { Numbers of } \\
\text { Farmers }\end{array}$ & Valid N & Valid \% \\
\hline $\begin{array}{l}\text { 1. Local variety + brushing }+ \text { burning }+ \text { clearing }+ \text { no ploughing }+ \text { manual ridging }+ \\
\text { no fertilizer }\end{array}$ & 281 & 987 & 28.5 \\
\hline $\begin{array}{l}\text { 2. Local variety }+ \text { brushing }+ \text { burning }+ \text { clearing }+ \text { no ploughing }+ \text { manual ridging }+ \\
\text { fertilizer }\end{array}$ & 719 & 987 & 72.8 \\
\hline $\begin{array}{l}\text { 3. Local variety }+ \text { no brushing }+ \text { no burning }+ \text { no clearing }+ \text { mechanical ploughing }+ \\
\text { mechanical ridging }+ \text { no fertilizer }\end{array}$ & 628 & 987 & 63.6 \\
\hline $\begin{array}{l}\text { 4. } \text { Local variety }+ \text { no brushing }+ \text { no burning }+ \text { no clearing }+ \text { mechanical ploughing }+ \\
\text { mechanical ridging }+ \text { fertilizer }\end{array}$ & 691 & 987 & 70 \\
\hline $\begin{array}{l}\text { 5. Improved variety }+ \text { brushing }+ \text { burning }+ \text { clearing }+ \text { no ploughing }+ \text { manual } \\
\text { ridging }+ \text { fertilizer }\end{array}$ & 235 & 987 & 23.8 \\
\hline $\begin{array}{l}\text { 6. Improved variety }+ \text { no brushing }+ \text { no burning }+ \text { no clearing }+ \text { Mechanical } \\
\text { ploughing }+ \text { mechanical ridging }+ \text { fertilizer }\end{array}$ & 238 & 987 & 24.1 \\
\hline
\end{tabular}

Note. NB: Each farmer can use several systems according to the fertility of the farm, the variety, the market (customer), etc.

Source: Field survey data, 2013 and 2016.

According to the data collected from the survey and when cross check with the research data, the mean yield of cassava root ranged from 5.8 to 25 tons per hectare according to the system. Therefore, the root yield value used for calculations is as follows: $5.8 \mathrm{t} / \mathrm{ha}$ for systems $1 \& 3,11 \mathrm{t} / \mathrm{ha}$ for systems $2 \& 4$ and $25 \mathrm{t} /$ ha for systems $5 \& 6$. 
Cassava stems are another source of revenue to cassava farmers. It's used by the farmers for replanting or sold to another farmer. Based on the survey, about 240 to 800 bundles of stems are harvested from 1 ha of cassava farm. The number of bundles used in the calculations is as follows: systems $1 \& 3$ (240 bundles), system $2 \& 4$ (600 bundles) and system $5 \& 6$ ( 800 bundles).

Cassava leaves was not taken into account in the calculation because of its negative impact on the cassava root yield. Maybe, the revenue generated by the harvested leaves could have compensated for the loss of cassava roots but this analysis did work on that scenario. The yield value used for calculation is the normal one with minimum leave harvesting for domestic consumption. According to several scientific publications specially "Evaluation of Cassava for Leaf and Root Production in Sierra Leone" (Dahniya, 1994), Cassava varieties reacted differently to leaf harvest in terms of tuberous root yields. Compared with plants whose leaves were not harvested, there was a total fresh tuberous root yield reduction ranging from $22 \%$ to $42 \%$ when leaves were harvested monthly. As the yield used to perform PAM is the normal yield without leave harvesting.

3.2.1 Policy Analysis Matrix for Fresh Cassava Storage Root Production for One Hectare of Production (Survey Scenario)

This scenario is based on the normal situation without any unexpected bad occurrence or change of climate.

The Table 5 shows the competitiveness indicators of the 6 selected fresh cassava storage root production systems.

The data on the table based on PAM analysis indicates that, cassava fresh root systems 1, 2, 3, 4, 5 and 6 present Domestic Resource Cost ratio (DRC: respectively 0.21, 0.241, 0.388, 0.224, 0.119 and 0.110 ) less than 1 . The cassava fresh root production systems using improved varieties have the best DRC (0.119 and 0.110$)$ compared to the systems using local varieties. Similarly, we find that systems using fertilizer have an interesting DRC indicating a comparative advantage and a good competitiveness. All the six cassava fresh root production systems widely used in Sierra Leone have comparative and competitive advantages but the cassava fresh root production systems which use improved varieties are more competitive. It is better for the Sierra Leone to produce locally the cassava fresh root than import it for processing or consumption. In other hand, using domestic resources to produce 1ha of cassava root is more profitable than buying the same quantity on international market. The majority of producers uses resources efficiently and contributes effectively to the national income at social prices.

The Cost-Benefit Ratio (CBR) is the ratio of costs (tradable and domestic costs) over the gross benefits. For all cassava fresh root production systems, the CBR are less than 1 (CBR within 0.14 to 0.42 ). The values of this ratio confirm that, the cassava fresh root production activity is economically profitable to the producers especially when using improved varieties and fertilizer.

NPCI values are greater than one (NPCI $>1$ ). Suggesting that, farmers are not protected for tradable inputs such as fertilizers and other agro-chemicals. This was confirmed with EPC values which are less than one $(\mathrm{EPC}<1)$ explaining tax existence for farmers.

Table 5. PAM for fresh cassava storage root production for one hectare of production (Survey Scenario)

\begin{tabular}{|c|c|c|c|c|c|c|c|c|}
\hline & & \multicolumn{7}{|c|}{ Indicators of competitiveness and policy effect } \\
\hline & & CBR & DRC & NPC & NPCI & EPC & PC & SRP \\
\hline No. & Cassava fresh root production systems & $\begin{array}{l}\mathbf{C B R}= \\
(\mathbf{F}+\mathbf{G}) / \mathbf{E}\end{array}$ & $\begin{array}{l}\text { DRC }= \\
\text { G/(E-F) }\end{array}$ & $\begin{array}{l}\text { NPC }= \\
\mathbf{A} / \mathbf{E}\end{array}$ & $\begin{array}{l}\text { NPCI }= \\
B / F\end{array}$ & $\begin{array}{l}\mathbf{E P C}= \\
(\mathbf{A}-\mathrm{B}) /(\mathbf{E}-\mathrm{F})\end{array}$ & $\begin{array}{l}\mathbf{P C}= \\
\mathbf{D} / \mathrm{H}\end{array}$ & $\begin{array}{l}\mathrm{SRP}= \\
\mathbf{L} / \mathbf{E}\end{array}$ \\
\hline 1. & $\begin{array}{l}\text { Local variety }+ \text { brushing }+ \text { burning }+ \text { clearing }+ \\
\text { no ploughing }+ \text { manual ridging }+ \text { no fertilizer }\end{array}$ & 0.42 & 0.421 & 1 & 1.176 & 1 & 1 & 0 \\
\hline 2. & $\begin{array}{l}\text { Local variety }+ \text { brushing }+ \text { burning }+ \text { clearing }+ \\
\text { no ploughing }+ \text { manual ridging }+ \text { fertilizer }\end{array}$ & 0.29 & 0.241 & 1 & 1.02 & 0.998 & 1 & -0 \\
\hline 3. & $\begin{array}{l}\text { Local variety }+ \text { no brushing }+ \text { no burning }+ \text { no clearing }+ \\
\text { mechanical ploughing }+ \text { mechanical ridging }+ \text { no fertilizer }\end{array}$ & 0.39 & 0.388 & 1 & 1.176 & 1 & 1 & 0 \\
\hline 4. & $\begin{array}{l}\text { Local variety }+ \text { no brushing }+ \text { no burning }+ \text { no clearing }+ \\
\text { mechanical ploughing }+ \text { mechanical ridging }+ \text { fertilizer }\end{array}$ & 0.28 & 0.224 & 1 & 1.02 & 0.998 & 1 & -0 \\
\hline 5. & $\begin{array}{l}\text { Improved variety }+ \text { brushing }+ \text { burning }+ \text { clearing }+ \\
\text { no ploughing }+ \text { manual ridging }+ \text { fertilizer }\end{array}$ & 0.15 & 0.119 & 1 & 1.02 & 0.999 & 1 & -0 \\
\hline 6. & $\begin{array}{l}\text { Improved variety }+ \text { no brushing }+ \text { no burning }+ \text { no clearing } \\
+ \text { Mechanical ploughing }+ \text { mechanical ridging }+ \text { fertilizer }\end{array}$ & 0.14 & 0.11 & 1 & 1.02 & 0.999 & 1.02 & 0.014 \\
\hline
\end{tabular}

Source: Field survey data, 2013 and 2016. 
3.2.2 Policy Analysis Matrix for Fresh Cassava Storage Root Production for One Hectare of Production (Sensitivity Analysis with $25 \%$ and $50 \%$ of Yield Loss)

Agricultural production is influenced by several biotic and abiotic factors. The most important ones are climate change, unexpected pests or diseases attacks. In general, these factors if occurred may cause a drop in yield of the tuber. To analyse the robustness of cassava production systems in Sierra Leone in relation towards those factors, we performed simulations of $25 \%$ to $50 \%$ yield loss.

From the PAM analysis Tables 6 and 7, it appears that all production systems remain profitable and competitive with a loss of $25 \%$ of cassava yield. However, comparative advantage always remains in favour of systems using improved variety and/or fertilizer.

Table 6. Policy analysis matrix for fresh cassava storage root production with $25 \%$ of the yield loss

\begin{tabular}{|c|c|c|c|c|c|c|c|c|}
\hline & & \multicolumn{7}{|c|}{ Indicators of competitiveness and policy effect } \\
\hline & & CBR & DRC & NPC & NPCI & EPC & PC & SRP \\
\hline No. & Cassava fresh root production systems & $\begin{array}{l}\mathbf{C B R}= \\
(\mathbf{F}+\mathbf{G}) / \mathbf{E}\end{array}$ & $\begin{array}{l}\text { DRC }= \\
\text { G/(E-F) }\end{array}$ & $\begin{array}{l}\mathbf{N P C}= \\
\mathbf{A} / \mathbf{E}\end{array}$ & $\begin{array}{l}\text { NPCI }= \\
\text { B/F }\end{array}$ & $\begin{array}{l}\mathbf{E P C}= \\
(\mathbf{A}-\mathbf{B}) /(\mathbf{E}-\mathbf{F})\end{array}$ & $\begin{array}{l}\mathrm{PC}= \\
\mathrm{D} / \mathrm{H}\end{array}$ & $\begin{array}{l}\mathrm{SRP}= \\
\mathbf{L} / \mathbf{E}\end{array}$ \\
\hline 1. & $\begin{array}{l}\text { Local variety }+ \text { brushing }+ \text { burning }+ \text { clearing }+ \\
\text { no ploughing }+ \text { manual ridging }+ \text { no fertilizer }\end{array}$ & 0.51 & 0.514 & 1 & 1.176 & 1 & 1 & 0 \\
\hline 2. & $\begin{array}{l}\text { Local variety }+ \text { brushing }+ \text { burning }+ \text { clearing }+ \\
\text { no ploughing }+ \text { manual ridging }+ \text { fertilizer }\end{array}$ & 0.35 & 0.293 & 1 & 1.02 & 0.998 & 1,00 & -0 \\
\hline 3. & $\begin{array}{l}\text { Local variety }+ \text { no brushing }+ \text { no burning }+ \text { no clearing }+ \\
\text { mechanical ploughing }+ \text { mechanical ridging }+ \text { no fertilizer }\end{array}$ & 0.47 & 0.474 & 1 & 1.176 & 1 & 1,00 & 0 \\
\hline 4. & $\begin{array}{l}\text { Local variety }+ \text { no brushing }+ \text { no burning }+ \text { no clearing }+ \\
\text { mechanical ploughing }+ \text { mechanical ridging }+ \text { fertilizer }\end{array}$ & 0.33 & 0.272 & 1 & 1.02 & 0.998 & 1,00 & -0 \\
\hline 5. & $\begin{array}{l}\text { Improved variety }+ \text { brushing }+ \text { burning }+ \text { clearing }+ \\
\text { no ploughing }+ \text { manual ridging }+ \text { fertilizer }\end{array}$ & 0.19 & 0.148 & 1 & 1.02 & 0.999 & 1 & -0 \\
\hline 6. & $\begin{array}{l}\text { Improved variety }+ \text { no brushing }+ \text { no burning }+ \text { no clearing } \\
+ \text { Mechanical ploughing }+ \text { mechanical ridging }+ \text { fertilizer }\end{array}$ & 0.18 & 0.138 & 1 & 1.02 & 0.999 & 1.02 & 0.018 \\
\hline
\end{tabular}

Source: Field survey data, 2013 and 2016.

Table 7. Policy analysis matrix for fresh cassava storage root production with $50 \%$ of yield loss

\begin{tabular}{|c|c|c|c|c|c|c|c|c|}
\hline & & \multicolumn{7}{|c|}{ Indicators of competitiveness and policy effect } \\
\hline & & CBR & DRC & NPC & NPCI & EPC & PC & SRP \\
\hline No. & Cassava fresh root production systems & $\begin{array}{l}\mathbf{C B R}= \\
(\mathbf{F}+\mathbf{G}) / \mathbf{E}\end{array}$ & $\begin{array}{l}\text { DRC }= \\
\text { G/(E- F })\end{array}$ & $\begin{array}{l}\mathbf{N P C}= \\
\mathbf{A} / \mathbf{E}\end{array}$ & $\begin{array}{l}\text { NPCI }= \\
\mathbf{B} / \mathbf{F}\end{array}$ & $\begin{array}{l}\mathbf{E P C}= \\
(\mathbf{A}-\mathrm{B}) /(\mathbf{E}-\mathrm{F})\end{array}$ & $\begin{array}{l}\mathrm{PC}= \\
\mathrm{D} / \mathrm{H}\end{array}$ & $\begin{array}{l}\text { SRP }= \\
\mathbf{L} / \mathbf{E}\end{array}$ \\
\hline 1. & $\begin{array}{l}\text { Local variety }+ \text { brushing }+ \text { burning }+ \text { clearing }+ \\
\text { no ploughing }+ \text { manual ridging }+ \text { no fertilizer }\end{array}$ & 0.66 & 0.659 & 1 & 1.176 & 1 & 1 & 0 \\
\hline 2. & $\begin{array}{l}\text { Local variety }+ \text { brushing }+ \text { burning }+ \text { clearing }+ \\
\text { no ploughing }+ \text { manual ridging }+ \text { fertilizer }\end{array}$ & 0.44 & 0.375 & 1 & 1.02 & 0.998 & 1 & -0 \\
\hline 3. & $\begin{array}{l}\text { Local variety }+ \text { no brushing }+ \text { no burning }+ \text { no clearing }+ \\
\text { mechanical ploughing }+ \text { mechanical ridging }+ \text { no fertilizer }\end{array}$ & 0.61 & 0.608 & 1 & 1.176 & 1 & 1 & 0 \\
\hline 4. & $\begin{array}{l}\text { Local variety }+ \text { no brushing }+ \text { no burning }+ \text { no clearing }+ \\
\text { mechanical ploughing }+ \text { mechanical ridging }+ \text { fertilizer }\end{array}$ & 0.42 & 0.348 & 1 & 1.02 & 0.998 & 1 & -0 \\
\hline 5. & $\begin{array}{l}\text { Improved variety }+ \text { brushing }+ \text { burning }+ \text { clearing }+ \\
\text { no ploughing }+ \text { manual ridging }+ \text { fertilizer }\end{array}$ & 0.24 & 0.198 & 1 & 1.02 & 0.999 & 1 & -0 \\
\hline 6. & $\begin{array}{l}\text { Improved variety }+ \text { no brushing }+ \text { no burning }+ \text { no clearing } \\
+ \text { Mechanical ploughing }+ \text { mechanical ridging }+ \text { fertilizer }\end{array}$ & 0.23 & 0.184 & 1 & 1.02 & 0.999 & 1.03 & 0.023 \\
\hline
\end{tabular}

Source: Field survey data, 2013 and 2016.

\subsection{Determine the Profitability and Market Margins for Fresh Cassava Storage Roots (Producers)}

For all the cassava root production systems (Table 8), the private profits are positives and therefore the returns are above the normal. The producers can consider an expansion of cassava root production activities regardless the system. However, the systems using improved varieties and/or fertilizer offer more profits and opportunities for intensification and expansion through the use of fertilizers and other agricultural inputs like land. Positive values 
of social profits indicate that all systems generate enough profit to contribute to the development of the communities without any policy transfers. In other hand, social profits are greater than private profits and this suggests an overvalue exchange rate was used to import cheap cassava fresh root which made the financial profits to be lower than the true economic profits. This explains the existence of tax on farmers. The profitability coefficients $(\mathrm{PC})$ are equal to one $(\mathrm{PC}=1)$ and indicate a balance between social and economic benefits. There is no subsidy from the private to the social and vice versa.

Table 8. Profitability and margins for cassava fresh root production

\begin{tabular}{|c|c|c|c|c|c|c|c|c|c|c|c|c|c|}
\hline & \multicolumn{4}{|c|}{ Market } & \multicolumn{4}{|c|}{ Economic } & \multicolumn{4}{|c|}{ Divergences } & \multirow{2}{*}{ PC } \\
\hline & A & B & $\mathbf{C}$ & D & $\mathbf{E}$ & $\mathbf{F}$ & $\mathbf{G}$ & $\mathbf{H}$ & I & $\mathbf{J}$ & $\mathbf{K}$ & $\mathbf{L}$ & \\
\hline & $\mathrm{A}=\mathrm{Pf} \cdot \mathrm{Q}$ & $\mathrm{B}=\mathrm{Pt} \cdot \mathrm{Qt}$ & $\mathrm{C}=\mathrm{Pn} \cdot \mathrm{Qn}$ & $\mathbf{D}=\mathbf{A}-\mathbf{B}-\mathbf{C}$ & $\mathrm{E}=\mathrm{Pe} \cdot \mathrm{Q}$ & $\mathrm{F}=\mathrm{Pi} \cdot \mathrm{Qi}$ & $\mathrm{G}=\mathrm{Pd} \cdot \mathrm{Qd}$ & $\mathbf{H}=\mathbf{E}-\mathbf{F}-\mathbf{G}$ & $\mathrm{I}=\mathrm{A}-\mathrm{E}$ & $\mathrm{J}=\mathrm{B}-\mathrm{F}$ & $\mathrm{K}=\mathrm{C}-\mathrm{G}$ & $\mathrm{L}=\mathrm{I}-\mathrm{J}-\mathrm{K}$ & D/H \\
\hline 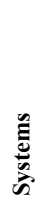 & 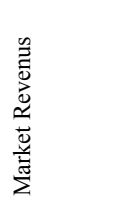 & 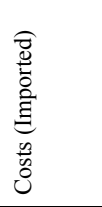 & 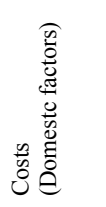 & 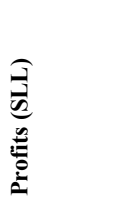 & 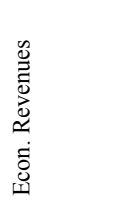 & 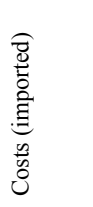 & 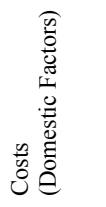 & 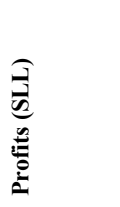 & 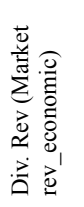 & 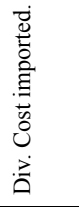 & 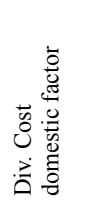 & 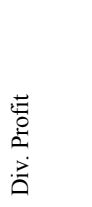 & 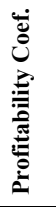 \\
\hline S1 & 3856560 & 2250 & 1623121 & 2231189 & 3856560 & 1913 & 1623121 & 2231527 & 0 & 338 & 0 & -338 & 1.0 \\
\hline S2 & 7961400 & 572250 & 1783121 & 5606029 & 7961400 & 561113 & 1783121 & 5617167 & 0 & 11138 & 0 & -11138 & 1.0 \\
\hline $\mathbf{S 3}$ & 3856560 & 2250 & 1496173 & 2358137 & 3856560 & 1913 & 1496173 & 2358475 & 0 & 338 & 0 & -338 & 1.0 \\
\hline S4 & 7961400 & 572250 & 1656173 & 5732977 & 7961400 & 561113 & 1656173 & 5744115 & 0 & 11138 & 0 & -11138 & 1.0 \\
\hline S5 & 15575200 & 572250 & 1783121 & 13219829 & 15575200 & 561113 & 1783121 & 13230967 & 0 & 11138 & 0 & -11138 & 1.0 \\
\hline S6 & 15575200 & 572250 & 1421173 & 13581777 & 15575200 & 561113 & 1656173 & 13357914 & 0 & 11138 & -235000 & 223862 & 1.02 \\
\hline
\end{tabular}

Source: Field survey data, 2013 and 2016.

\subsection{Major Opportunities and Constraints for Producers}

\subsubsection{SWOT Analysis}

The Kendall's coefficient of concordance indicates a very low degree of agreement among the tuber producers as to the ranking of their strengths, weaknesses, opportunities and threats even though P-values in the test statistics were highly significant (Table 9).

The major attributes of the root producers in the SWOT analysis could be referred to those highly ranked attributes but with a non-significant $\mathrm{P}$-value $(\mathrm{P}>0.05)$. In the regard, the major strengths of the tuber producers were their access to agricultural land for tuber production activities and labour for processing activities, whilst limited access to finance and credit facilities and high transportation cost of tubers were their major weaknesses. Availability of improved cassava varieties released by SLARI was their major opportunities whilst no external funding for tuber production and vehicle operators demand high transport fares were their major threats. 
Table 9. SWOT analysis for cassava root producers

\begin{tabular}{|c|c|c|c|c|c|}
\hline Strength & Freq. (\%) & ${ }^{\S}$ Rank & Weakness & Freq. (\%) & ${ }^{8}$ Rank \\
\hline $\begin{array}{l}* \text { Have access to agricultural land } \\
\text { for tuber production }\end{array}$ & 36.6 & 1 & * Limited access finance and credit facilities & 35.0 & 1 \\
\hline $\begin{array}{l}* \text { Have access to labour for tuber } \\
\text { production activities }\end{array}$ & 23.2 & 2 & * High transportation cost of tubers & 23.4 & 2 \\
\hline Easy access to planting materials & 13.0 & 3 & Limited access to market & 17.5 & 3 \\
\hline Have access to credit and finance & 8.9 & 4 & $\begin{array}{l}\text { Limited access agriculture machinery } \\
\text { and equipment }\end{array}$ & 14.6 & 4 \\
\hline Have processing facilities & 4.9 & 5 & Low agricultural productivity & 2.9 & 5 \\
\hline Member of farmer based association & 4.1 & 6 & High post-harvest loss & 2.2 & 6 \\
\hline $\begin{array}{l}\text { Strong knowledge and experience } \\
\text { in tuber production }\end{array}$ & 4.1 & 7 & Lack of training & 2.2 & 7 \\
\hline Have access to agricultural inputs & 3.3 & 7 & Lack of trust among value chain stakeholders & 1.5 & 8 \\
\hline High demand for cassava tubers & 1.2 & 8 & Lack of information & 0.7 & 9 \\
\hline Strong linkages with processors & 0.8 & 9 & & & \\
\hline Kendall's $W$ & 0.097 & & Kendall's $W$ & 0.097 & \\
\hline$P$-value & $<0.0001$ & & $P$-value & $<0.0001$ & \\
\hline Opportunity & Freq. (\%) & ${ }^{\S}$ Rank & Threat & Freq. (\%) & ${ }^{8}$ Rank \\
\hline $\begin{array}{l}\text { * Availability of improved cassava varieties } \\
\text { released by SLARI }\end{array}$ & 38.4 & 1 & * No external funding for tuber production & 34.0 & 1 \\
\hline Strong government and donor support & 19.6 & 2 & * Vehicle operators demand high transport fares & 22.7 & 2 \\
\hline $\begin{array}{l}\text { Availability of training on improved } \\
\text { agronomic practices }\end{array}$ & 12.3 & 3 & $\begin{array}{l}\text { Market diversity and competition with other } \\
\text { cassava-based products }\end{array}$ & 17.0 & 3 \\
\hline Availability of markets for sale of tubers & 11.6 & 4 & $\begin{array}{l}\text { Interest rates charged by financial } \\
\text { institutes are high }\end{array}$ & 14.9 & 4 \\
\hline Availability processing centres & 11.6 & 5 & $\begin{array}{l}\text { High cost of agricultural machinery, } \\
\text { equipment and inputs }\end{array}$ & 9.2 & 5 \\
\hline Strong linkages with $\mathrm{VC}$ actors & 6.5 & 6 & $\begin{array}{l}\text { High pre (pest and disease) and post } \\
\text { (tuber deterioration) harvest loss }\end{array}$ & 2.1 & 6 \\
\hline Kendall's $W$ & 0.084 & & Kendall's $W$ & 0.054 & \\
\hline$P$-value & $<0.0001$ & & P-value & $<0.0001$ & \\
\hline
\end{tabular}

Note. Freq.: Frequency count; ${ }^{\S}$ Rank: Kendall's ranking; *: Test statistics not significant (P $\left.>0.05\right)$; Kendall's W: Kendall's coefficient of concordance.

Source: Field survey data, 2013.

\subsubsection{Major Farming Constraints}

According to the farmers, the main constraints they are facing when producing local varieties are mainly pest/disease management (66.5\% of the respondents) and low cassava yield (10.4\%). For the improved varieties, the constraints are also pest and diseases management (58.5\%), Cassava quality (14.8\%) and high farming labour ( $14.5 \%$ of farmers). See Figure 2 below. 


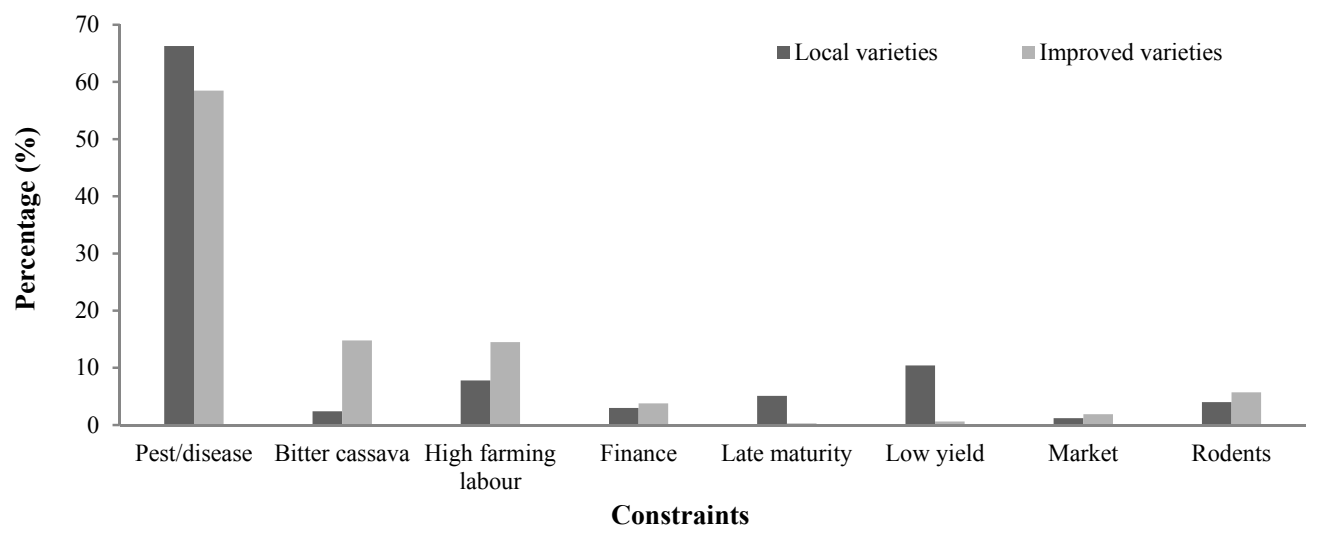

Figure 2. Constraints cited by the producers

Table 10. Potential cassava root production systems in Sierra Leone

\begin{tabular}{|c|c|}
\hline System & Potential cassava root production systems \\
\hline 1 & L.variety + brushing + burning + clearing + no ploughing + manual Ridging + fertilizer \\
\hline 2 & L.variety + brushing + burning + clearing + ploughing + manual Ridging + fertilizer \\
\hline 3 & L.variety + brushing + burning + clearing + no ploughing + mechanical ridging + fertilizer \\
\hline 4 & L.variety + brushing + burning + clearing + no ploughing + manual Ridging + no fertilizer \\
\hline 5 & L.variety + brushing + burning + clearing + ploughing + manual Ridging + no fertilizer \\
\hline 6 & L.variety + brushing + burning + clearing + no ploughing + mechanical ridging + no fertilizer \\
\hline 7 & L.variety + brushing + burning + clearing + ploughing + manual Ridging + no fertilizer \\
\hline 8 & L.variety + brushing + burning + clearing + ploughing + mechanical ridging + no fertilizer \\
\hline 9 & L.variety + brushing + burning + clearing + ploughing + mechanical ridging + fertilizer \\
\hline 10 & L.variety + no brushing + no burning + no clearing + no ploughing + manual Ridging + fertilizer \\
\hline 11 & L.variety + no brushing + no burning + no clearing + ploughing + manual Ridging + fertilizer \\
\hline 12 & L.variety + no brushing + no burning + no clearing + no ploughing + mechanical ridging + fertilizer \\
\hline 13 & L.variety + no brushing + no burning + no clearing + no ploughing + manual Ridging + no fertilizer \\
\hline 14 & L.variety + no brushing + no burning + no clearing + ploughing + manual Ridging + no fertilizer \\
\hline 15 & L.variety + no brushing + no burning + no clearing + no ploughing + mechanical ridging + no fertilizer \\
\hline 16 & L.variety + no brushing + no burning + no clearing + ploughing + manual Ridging + no fertilizer \\
\hline 17 & L.variety + no brushing + no burning + no clearing + ploughing + mechanical ridging + no fertilizer \\
\hline 18 & L.variety + no brushing + no burning + no clearing + ploughing + mechanical ridging + fertilizer \\
\hline 19 & I.variety + brushing + burning + clearing + no ploughing + manual Ridging + fertilizer \\
\hline 20 & I.variety + brushing + burning + clearing + ploughing + manual Ridging + fertilizer \\
\hline 21 & I.variety + brushing + burning + clearing + no ploughing + mechanical ridging + fertilizer \\
\hline 22 & I.variety + brushing + burning + clearing + no ploughing + manual Ridging + no fertilizer \\
\hline 23 & I.variety + brushing + burning + clearing + ploughing + manual Ridging + no fertilizer \\
\hline 24 & I.variety + brushing + burning + clearing + no ploughing + mechanical ridging + no fertilizer \\
\hline 25 & I.variety + brushing + burning + clearing + ploughing + manual Ridging + no fertilizer \\
\hline 26 & I.variety + brushing + burning + clearing + ploughing + mechanical ridging + no fertilizer \\
\hline 27 & I.variety + brushing + burning + clearing + ploughing + mechanical ridging + fertilizer \\
\hline 28 & I.variety + no brushing + no burning + no clearing + no ploughing + manual Ridging + fertilizer \\
\hline 29 & I.variety + no brushing + no burning + no clearing + ploughing + manual Ridging + fertilizer \\
\hline 30 & I.variety + no brushing + no burning + no clearing + no ploughing + mechanical ridging + fertilizer \\
\hline 31 & I.variety + no brushing + no burning + no clearing + no ploughing + manual Ridging + no fertilizer \\
\hline 32 & I.variety + no brushing + no burning + no clearing + ploughing + manual Ridging + no fertilizer \\
\hline 33 & I.variety + no brushing + no burning + no clearing + no ploughing + mechanical ridging + no fertilizer \\
\hline 34 & I.variety + no brushing + no burning + no clearing + ploughing + manual Ridging + no fertilizer \\
\hline 35 & I.variety + no brushing + no burning + no clearing + ploughing + mechanical ridging + no fertilizer \\
\hline 36 & I.variety + no brushing + no burning + no clearing + ploughing + mechanical ridging + fertilizer \\
\hline
\end{tabular}

Note. L.variety means Local variety and I.variety means Improve variety.

Source: Field survey data, 2013. 


\section{Conclusion and Recommendations}

\subsection{Conclusion}

PAM was used to analyse the efficiencies and competitiveness of the selected fresh cassava storage root production systems in Sierra Leone. The results revealed that, the discounting potential revenue from stems and cassava leaves in storage root production, all the 6 selected cassava fresh root production systems widely used in Sierra Leone have comparative and competitive advantages but those that uses improved varieties and fertilizer have higher comparative and competitive advantages and profitable even though producers are not protected from tradable, taxed inputs. The production systems also remain profitable even at $25 \%$ and $50 \%$ yield loss.

Therefore, it is better for Sierra Leone to produce locally the cassava fresh root than import it for processing or consumption. In other hand, using domestic resources to produce 1ha of cassava root is more profitable than buying the same quantity on international market. The majority of producers uses resources efficiently and contributes effectively to the national income at social prices.

The major strengths of the tuber producers in Sierra Leone were their access to agricultural land for tuber production activities and labour for production activities, whilst limited access to finance and credit facilities and high transportation cost of tubers were their major weaknesses.

\subsection{Recommendations/Action Plans for Cassava Industrialisation in Sierra Leone}

\subsubsection{Strong Farmer Linkages}

Enhancing linkages between processors, marketers and smallholders through well-planned out grower schemes and block farmer arrangements will strengthen supply chains. In situations where they are needed, going a step further to provide or bring in tailored service providers like finance to farmers to enable access to inputs will incentivize increased production and strengthen trust and loyalty bonds with the primary processor.

\subsubsection{Promotion of Improved Varieties}

Promoting access to and use of improved varieties that aligns to the targeted final end product, for example higher poundable trait for consumption, starch and dry matter content if supplying to processors, or higher resistance to disease for higher yields, etc. will go a long way in increasing the value of harvested produce, both to the farmer and to the primary processors.

\subsubsection{Access to Mechanization}

Enhancing the availability of mechanization, enable farmers to increase planted areas for commercial off-takers at reduced costs.

\subsubsection{Improved Infrastructure}

Improved access to farms through building better road networks in areas where cassava is grown has the potential to substantially reduce transportation costs and can make it easier for processors and traders to access sufficient volumes of supply.

\subsubsection{Better Awareness of Cassava's Potential}

Sustained efforts to increase awareness among all stakeholders including: to farmers on the potential benefits of farming cassava; to processors on the importance of maintaining quality and keeping production costs low; and to end-users on the various products and adoption/substitution prospects available based on a quality, supply consistency and pricing perspective.

\subsubsection{Product promotion}

\section{(1) High Quality Cassava Flour (HQCF)}

Promote and demonstrate feasibility of HQCF substitution for different products and prove market demand and sufficient supply for commercial use. As a parallel step, develop innovative incentives that will promote adoption rather than mandating inclusion, which has proven difficult to enforce in other environments.

(2) Dried Chips-for Animal Feed and for Export

Promote adoption of low-cost chipping machines and rack dryers among small farmers and cooperatives to enable them to produce at scale while keeping costs low.

\section{Acknowledgements}

This research would not have been possible without the collaboration of Dr. Jim B. A. Whyte and the International Institute of Tropical Agriculture in Sierra Leone, Nigeria and Benin (IITA) team with the various 
centers of the Sierra Leone Agricultural Research Institute (SLARI). The authors wish to acknowledge the Government of Sierra Leone through the Ministry of Agriculture Forestry and Food security (MAFFS), The World Bank and The West African Agricultural Productivity Programme (WAAPP) team for the financial and technical support provided for this project. Special thanks to the Njala Agricultural Research Centre (NARC) Scientists, Dr. Abdul Rahman Conteh-Director and Prof. S. N Fomba (Former Director) for their unflinching supports given to this work and excellent research assistance. A more in-depth thanks and appreciation to our former and present SLARI Director Generals Dr. Dixion, Dr. Joseph Kargbo and Dr. Methew L. S Boku for their technical input and supervision throughout this study. I wish to thank colleagues from all SLARI centers who participated in the data collection and inputting.

\section{References}

Abiodun, O. O., \& Adefemi, J. O. (2016). Profitability of Cassava-Based Production Systems. Journal of Human Ecology, 56, 196-203. Retrieved from https://www.researchgate.net/publication/311321258

Basu, K., \& Van, P. H. (1998). The Economics of Child Labor. American Economic Review, 88, 412-427. Retrieved from http://www.jstor.org/stable/116842

Cochran, W. G. (1977). Sampling techniques (3rd ed.). New York: John Wiley and Sons.

Dahniya, M. T. (1994). An overview of cassava in Africa. Afr. Crop Sci. J., 4, 337-343. Retrieved from https://tspace.library.utoronto.ca/bitstream/1807/47741/1/cs94045.pdf

Elijah, O. A., \& Okoruwa, V. (2006). Analysis of Child Labour and School attendance in Nigeria: The present and future implications (Dept. of Agricultural Economics, Faculty of Agriculture and Forestry, University of Ibadan, Ibadan, Oyo State, Nigeria).

Fomba, S., Dixon, A. G. O., Onadipe, O. O., Alenkhe, E. B., \& Sanni, L. O. (2011). Cassava Value Chain Development by Supporting Processing and Value Addition by Small and Medium Enterprises in West Africa, Sierra-Leone. Technical Report August 2008-August 2011 (p. 43) Retrieved from http://common-fund.org/fileadmin/user...37/Report.../CFC_Sierra_Leone_Report.pdf

Food and Agricultural Organization Statistics (FAOSTAT). (2015). Consumption and Trade in Cassava Products. Retrieved from http://www.fao.org/3/a-i4691e.pdf

Food and Agricultural Organization Statistics (FAOSTAT). (2015). Trend of Cassava Production in Nigeria, From 1980-2013. Retrieved from http://www.fao.org/3/a-i4691e.pdf

Hillocks, R. J. M., \& Bellotti, A. C. (2002). Cassava Biology, Production and Utilization (pp. 67-90). CAB International, Wallingford, UK. https://doi.org/10.1079/9780851995243.0000

Mahmood, N. (2016). Draft Report on Yield Gap Analysis of Selected Commodities in Sierra Leone. CORAF/WECARD/MAFFS. Retrieved from http://www.coraf.org/ahcstaff/.../1ํ-DRAFT-YIELD-GAPANALYSIS-SIERRA-LEONE.pd...

Ministry of Agriculture, Forestry and Food Security. (2009a). National Sustainable Agriculture Development Plan 2010-2030.

Ministry of Agriculture, Forestry and Food Security/Planning, Evaluation, Monitoring and Statistics Division (MAFFS/PEMSD). (2015). Agricultural Statistics Bulletin (Vol. 4). Sierra Leone.

Nigerian Institute of Social and Economic Research. (2013). Reducing Food Crop Losses through Post-Harvest Management in Nigeria. NISER Unpublished Research Study, 2013. NISER, Ibadan. Retrieved from https://ageconsearch.umn.edu/.../Babalola\%20D.\%20A\%20and\%20Olayemi\%20J.\%2...

Nweke, F. I. (2004). New challenges in the cassava transformation in Nigeria and Ghana (p. 118). Environment and Production Technology Division, International Food Policy Research Institute, Washington D.C., USA.

Nweke, F. I., Spencer, D. S. C., \& Lynam, J. K. (2002). The cassava transformation: Africa's best kept secret (p. 273). Michigan State University, East Lansing, Michigan. Retrieved from https://www.amazon.com/ Cassava-Transformation-Africas-Best-Kept-Secret/.../08701...

Oyekanmi, A. A., \& Okeleye, K. A. (2007). Cassava Production Systems across Some Agro-ecological Zones in South West-North West Axis of Nigeria. Asian Journal of Plant Sciences, 6, 158-162. https://doi.org/ 10.3923/ajps.2007.158.162

SSL. (2010). Annual Economic Survey (Vol. 2). Economic Statistics Division. Retrieved from https://africaopendata.org/dataset/...4aa5.../annualeconomicsurveyreport2009.pdf 
The State of Food Security and Nutrition in Sierra Leone. (2011). Comprehensive Food Security and Vulnerability Analysis (CFSVA). World Food Programme, Republic of Sierra Leone and UNICEF, Funding by European Union.

UNFPA/GOSL/EU. (2004). Population and Housing Census, Report Embargoed Until 11:00 AM Thursday 23rd February 2006. UNFPA/GOSL/EU. Retrieved from http://www.statistics.sl

Westby, A. (2008). Cassava Utilization, Storage and Small-Scale Processing. In R. Hillock, J. Thresh, \& A. C. Bellotti (Eds.), Cassava Biology, Production and Utilization (pp. 67-90). CABI Publishing, Wallingford, UK. https://doi.org/10.5897/AJAR2013.8261

\section{Copyrights}

Copyright for this article is retained by the author(s), with first publication rights granted to the journal.

This is an open-access article distributed under the terms and conditions of the Creative Commons Attribution license (http://creativecommons.org/licenses/by/4.0/). 